\title{
The effect of online consumer socialization on buying intentions
}

\author{
*Zaryab Sheikha ${ }^{1}$, Liu YeZhenga ${ }^{2}$, Tahir Islam ${ }^{3}$, Ikram Ullah Khan ${ }^{4}$, Zahid Hameed \\ School of Management, Hefei University of Technology, P.R. of China ${ }^{1}$ \\ Department of Management Sciences, Beaconhouse National University, Lahore, Pakistan ${ }^{1}$ \\ School of Economics and Management, Tongji University, Shanghai, P.R. of China ${ }^{3}$ \\ Institute of Management Sciences, University of Science and Technology of Bannu, Pakistan ${ }^{4}$ \\ Department of Management and Social Sciences, Khawaja Fareed University of Engineering \\ and Information Technology, Rahim Yar Khan, Pakistan ${ }^{5}$
}

\begin{abstract}
Social media has become very popular nowadays and it is considered a suitable online platform for consumer socialization through peer communication. Social media is a fastest and effective way to share information with others. Presently, two billion social media accounts are active globally. Online consumer socialization plays a vital role in determining the purchase intentions of consumers in the era of digital natives. Peer consumers communicate with each other using social media websites which allow consumers to socialize and share the market information and their experiences related to products and services which affect consumer purchase intentions. This research study empirically investigates the impact of peer communication using social media websites with two important antecedents, i.e., tie strength with peers and identification with the peer group on purchase intentions with the moderating role of need for uniqueness between peer communication and purchase intentions. The findings reveal that the two antecedents have a positive impact on peer communication and online consumer socialization through peer communication has a significant impact on purchase intentions. The study has theoretical and practical implications.
\end{abstract}

Keywords: social media, consumer socialization, peer communication, purchase intentions

\section{Introduction}

The Internet has changed the consumer's lives, especially the involvement of social media is determining the way of consumers communication at a platform. According to Ahuja and Galvin (2003); Zhang and Daugherty (2009) social media permit users to communicate with each other by adding networks of friends and facilitates communication among peer groups. Social media through peer communication, changing the consumer behaviour and acting as a platform for consumer socialization (Okazaki, 2009).

\section{Online Consumer Socialization}

Consumer socialization theory is best described by Ward (1974). He stated that collective processes by which young people acquire skills, knowledge, and attitudes from others through communication which help them to act as consumers in the 


\section{INTERNATIONAL CONFERENCE ON BUSINESS, MANAGEMENT AND FINANCE}

\section{UNITED KINGDOM | LONDON | March 7-9,2019}

marketplace is known as consumer socialization. Ward (1974) also stated that communication among consumers influences their behavioral, emotional and cognitive attitudes. Consumers learn consumption related attitudes, skills and knowledge in the marketplace with the help of socialization (De Gregorio \& Sung, 2010; Moschis \& Churchill Jr, 1978). One of the most accepted socialization agents are peer groups which have been considered to be highly significant in determining consumption related decision making (Singh, Chao, \& Kwon, 2006). Social media is also considered to be an important agent of consumer socialization where people communicate to each other via internet, specially using social networking sites which provides virtual space to users (islam, Sheikh, Hameed, Khan, \& Azam, 2018; Sheikh, Islam, Rana, Hameed, \& Saeed, 2017; Wang, Yu, \& Wei, 2012). Online consumer socialization happens among peers with the help of social media which provide three conditions. At first, the communication tools like instant messaging, blogs, and social networking sites make the socialization process simple and convenient (Khan et al., 2017). For instance, Ahuja and Galvin (2003) in their study "virtual communities" found that through online communication, new members can quickly learn task related knowledge and skills and can socialize easily intro virtual groups through their interactions with other members. Secondly, the number of consumers who are visiting social media websites is growing and they help each other in finding information by communicating to each other online to take different utilization related decisions (Lueg, Ponder, Beatty, \& Capella, 2006). Third, social media has huge number of friends or peers who are performing their roles as socialization agents which provides evaluation of products and immense product knowledge to their peers or friends as a result of socialization which is another feature of social media to assist and educate users for providing information (Gershoff \& Johar, 2006; Taylor, Lewin, \& Strutton, 2011). Depicting the socialization framework of consumers, Taylor et al. (2011) concluded that the attitude of online consumers towards social network advertising significantly depend on socialization factors (i.e., peers).

\section{Socialization Agent: Peers}

The literature on consumer socialization pointed that ahead of a family member, the primary socialization agents are peers (Köhler, Rohm, de Ruyter, \& Wetzels, 2011). Consumer attitude has a significant influence towards services and products because of their consumption related interactions with peers (Mukhopadhyay \& Yeung, 2010). Clear evidence can be found from past research that peer communication has a significant impact on shopping orientations (Lueg et al., 2006), attitude towards advertising (De Gregorio \& Sung, 2010), and consumer decision making (Islam, Attiq, Hameed, Khokhar, \& Sheikh, 2018).

Also, Wang et al. (2012) confirm that peer communication can significantly shape the consumer intentions to buy through social media websites.

\section{Research Objectives}

The objective of this research study is to determine the impact of online consumer socialization on purchase intentions by investigating the preselected antecedents of consumer socialization and moderating role of need for uniqueness that how it strengthen or 


\section{INTERNATIONAL CONFERENCE ON BUSINESS, MANAGEMENT AND FINANCE}

\section{UNITED KINGDOM | LONDON | March 7-9,2019}

weaken the effect of peer communication on purchase intentions. This study will contribute in the body of knowledge and help practitioners to form their business strategies considering the social media settings and peer involvement in the purchase decision of peer consumers.

\section{Research Model and Hypothesis Development}

\section{Tie Strength with Peers}

Word of Mouth (WOM) communications has great influence on strengthening the ties with peers on social media (Brown, Broderick, \& Lee, 2007; De Bruyn \& Lilien, 2008). Tie strength with peers is defined as the degree that shows the willingness of a peer to maintain some relationship with other peers via social media. The relationship may be very casual, like with acquaintances or strangers or may be very close, such as close friends (Wang et al., 2012). Useful knowledge is more likely to be transferred through strong ties of the peer group (Levin $\&$ Cross, 2004) and weak ties have less influence no receivers than that of strong ties of the peer group (De Bruyn \& Lilien, 2008; Smith, Menon, \& Sivakumar, 2005). The strong tie between an individual and his or her peers in the context of social media is more likely to lead to communication about the product than a weak tie in the peer group (Wang et al., 2012). Therefore, the research leads to the following hypothesis:

H1: Tie strength with peers is positively associated with peer communication.

\section{Identification with the Peer Group}

The significant determinant of simulated community participation is identification with the peer group (Dholakia, Bagozzi, \& Pearo, 2004), like the persons wants to maintain a positive, self-defining relationship and develops we-intentions with the group, when identification with the group has been recognized (Bagozzi \& Dholakia, 2002; Islam, Wei, Sheikh, Hameed, \& Azam, 2017), also it places better value on associations with the community (Nambisan \& Baron, 2007), and the peers are eager to involve in community happenings (Algesheimer, Dholakia, \& Herrmann, 2005). Therefore, the study leads to form the following hypothesis: $\mathrm{H} 2$ : Identification with the peer group is positively associated with the peer communication.

\section{Peer Communication}

Consumers, corporation, and societies have been transformed by the internet and simulated communities with extensive access to information enhanced social networking and boosted communication facilities (Kucuk \& Krishnamurthy, 2007).

Peer communication is linked with learning about consumption, like product involvement, brand likings, or purchase intentions. Consumer attitude or behaviour towards purchase intention is the resultant of consumer's interaction over a social platform with socialization agents (Zaichkowsky, 1985). A study in the USA market discovered that consumer generated reviews have been read by $62 \%$ US online consumers and $98 \%$ of these consumers find that these online reviews are trustworthy; $80 \%$ of them said that reading such online reviews have strongly affected their purchase intentions (Statistics). Peer communication through social networking websites generate content and reviews about products and services and affect the purchase intentions of consumers (Pookulangara \& Koesler, 2011).

$\mathrm{H} 3$ - Peer Communication through social media websites has a positive 
relation with purchase intentions.

\section{Moderating Role of Need for Uniqueness}

An individual's decisions are being affected by the social influence of the other members of the community because that individual shows his concern about his or her behavior which creates his or her impression in front of the other community members (Amaldoss \& Jain, 2005). Willingness to produce WOM is also affected by consumer's need for uniqueness (Cheema \& Kaikati, 2010) or act according to the other's preferences (Irmak, Vallen, \& Sen, 2010).

Need for uniqueness has a substantial moderating effect on consumer evaluations in the consumer socialization process. When other consumers serve as the reference group, low uniqueness consumers are less likely to influence others as compare to high uniqueness consumers which are more likely to influence other consumers purchase intentions because of their high uniqueness power for product purchases (Irmak et al., 2010). Impact of peer communication on purchase intentions through social media websites is highly moderated by consumers need for uniqueness (Wang et al., 2012). Also, Tian, Bearden, and Hunter (2001) found that among high uniqueness consumers "counterconformity motivations" can be activated by peer reviews or recommendations; if they think that others are too similar to them such as when they smell a threat to their identity. Therefore, it is proposed that the impact of peer communication on social commerce intentions is highly moderated by consumers need for uniqueness. Thus, the study leads to form the following hypothesis:

$\mathrm{H} 4$ : Need for uniqueness moderates the association between peer communication and purchase intentions.

Figure-1: Research Model

\section{Research Methodology}

1. Instrument Development and Data Collection

The measurements for the present study were derived from past literature related to the constructs used in our research framework. All items of the constructs were adopted from the validated scale of Wang et al. (2012). All items were measured using a 7-point likert scale ranging from strong disagree (1) to strongly agree (7).

Data was collected from social media users in Pakistan using different means, i.e., emails, social media and snow balling, brand fan pages of social media users, instant messaging groups and through social media pages of online stores targeting the diverse population of different age, income, education, gender, experience of using social media websites and profession. The data were collected in one month time period (September 2016) using 
an online survey questionnaire. We received 250 responses from different sources and after carefully checking the responses received from respondents, 25 responses were identified as invalid, leaving 225 responses as our sample for analysis. This sample size is considered adequate for good analysis as recommended by Krejcie and Morgan (1970).

\section{Analysis and Results}

The data was analyzed using Structural Equation Modeling (SEM) method, using AMOS software has been used. It revealed that most of the respondents were male, i.e., $75 \%$ and majority (78\%) respondents were of younger age, i.e., 18-30 years old. This implies that majority of the social media users are young Pakistani people. The results also indicate that $60 \%$ of the respondents were students and the monthly income level of most respondents was $\mathrm{PKR}=20,000 /-$

\section{Structural Model}

The reliability of the model constructs was determined using AMOS software. Construct reliability can be checked that if the instrument items are free from random error and consistent results are being produced. The most common and comprehensive statistical tool to check the internal consistency of the items is Cronbach alpha $(\alpha)$ (Gefen \& Straub, 2000). The results of this study dataset revealed that the reliability of all constructs is more than 0.7 which is a minimum acceptance and considered good. The correlation among the constructs, descriptive statistics and alpha coefficients are presented in table-1

Table 1: Descriptive statistics and correlation among constructs

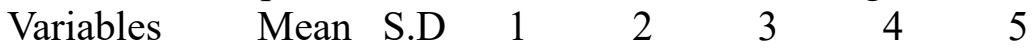

1. Ties Strength with Peers $3.45 \quad .73 \quad .81$

2. Identification with the Peer Group $3.57 \quad .68 \quad .28 * * \quad .73$

3. Peer Communication $\quad 3.48 \quad .67 \quad .56 * * .58 * * .72$

4. Need for Uniqueness $\quad 3.34 \quad .70 \quad .43 * * \quad .27 * * \quad .52 * * \quad .78$

5. Purchase Intentions $3.57 \quad .75 \quad .34 * * \quad .34 * * \quad .53 * * \quad .56^{* *} \quad .76$

Note: $\mathrm{N}=225$. Internal reliabilities (Alpha coefficients) for the variables are mentioned in bold on the diagonal; $* \mathrm{P}<.05, * * \mathrm{P}<.01$

The model fit R2 shows 0.370 for purchase intentions which means $37 \%$ of the variance in purchase intentions is was accounted for tie strength with peers, identification with the peer group and peer communication. This means purchase intention is affected by the antecedents of peer communication and peer communication itself. The $\mathrm{R} 2$ for peer communication is 0.461 which means $46 \%$ of the variance in peer communication is accounted 


\section{INTERNATIONAL CONFERENCE ON BUSINESS, MANAGEMENT AND FINANCE}

UNITED KINGDOM | LONDON | March 7-9,2019

by tie strength with peers and identification with the peer group. Therefore, the results show that the model has sufficient level of explanatory power. The results of model fitness have been shown in figure-2.

According to the results of structural equation modeling, the path coefficients (p-value), tie strength with peers $(0.397)$, identification with the peer group $(0.346)$ both have a significant impact on peer communication. Therefore, $\mathrm{H} 1$ and $\mathrm{H} 2$ are supported. Also, the path coefficient (p-value) of peer communication $(0.475)$ has a positive effect on purchase intentions. So, H3 is supported.

Figure 2: Structural Model Results

4. Moderator Analysis

The moderating effects of need for uniqueness ( $p$-value $=0.007$ ) is significant. This means that the moderating variable need for uniqueness strengthens the effect of peer communication on purchase intentions. Thus, H4 is supported. The analysis result of hypotheses has been presented in table-2.

Table-2: Regression Results

Causal Relationship

$$
\text { P Study Results }
$$

Ties Strength with Peers $\quad$---->

Identification with the Peer Group Supported

Explained variance

Peer Communication ----> PI $\quad .295$

Need for Uniqueness ----> P

PC* NU ----> PI

Explained variance

${ }^{*} \mathrm{P}<0.05,{ }^{* *} \mathrm{P}<0.01, * * * \mathrm{P}<0.001$

Table 3: Bootstrapping Results

$95 \%$ confidence intervals for indirect effect

Peer Communication

Effect SE Cls

Ties Strength with Peers
Unstandardized

$\begin{array}{lll}\mathrm{PC} & .397 & .397\end{array}$

$--->\quad P C$

.461

Standardized Std. Error

C.R

6.54

$.045 \quad 8.24$

$-2.70 \quad .007$

$* * *$

$* * *$

.370

Supported
Supported

$8.54 \quad * * * \quad$ Supported

$.0458 .44 \quad * * *$

Supported 


\section{INTERNATIONAL CONFERENCE ON BUSINESS, MANAGEMENT AND FINANCE}

UNITED KINGDOM | LONDON | March 7-9, 2019

Identification with the Peer Group $0.102 \quad 0.021 \quad 0.068 .0 .158$

\section{Mediation Analysis}

The mediation role of peer communication is also shown using a bootstrapping approach in structural equation modeling at a $95 \%$ confidence interval. It also has a significant impact on purchases intentions. The results of bootstrapping are shown in table-3. The control variables, age, gender, education, and experience of using social media website was also taken into account and the environment was controlled on the dataset to check the impact if it is different. The results of the control variables are insignificant, representing that none of the control variable is affecting the purchase intentions of peer consumers through social media websites.

\section{Discussion and Conclusion}

This study confirms that online consumer socialization has a great impact in determining purchase intentions. This research highlights that online consumer socialization through peer communication using social media websites has a significant relation with purchase intentions. Our study confirms that tie strength with peers and identification with the peer group have a positive relation with peer communication. This finding confirms our study previous literature (Algesheimer et al., 2005; Brown et al., 2007; De Bruyn \& Lilien, 2008; Dholakia et al., 2004; Nambisan \& Baron, 2007; Wang et al., 2012).

The study also concluded that peer communication has a positive effect on purchase intentions. Peers communication with each other through social media websites which helps consumers to form an online consumer socialization platform where consumers discuss personal things and related to products and services and experiences about it with other consumers. Thus, positively affects the purchase intentions. These findings align our results with the previous literature, e.g., (Kucuk \& Krishnamurthy, 2007; Pookulangara \& Koesler, 2011; Wang et al., 2012). Our study also determines the moderating effect of need for uniqueness about products and services on purchase intentions. This research revealed that moderating variable need for uniqueness has made the impact of peer communication on purchase intentions stronger. Consumers like to be unique from their peer group and follow the purchase of their peer consumers and try to leave an image of themselves as unique product or service buyer which strengthen the impact of peer communication on purchase intentions. This correspond our findings with the results of Cheema and Kaikati (2010); (Tian et al., 2001; Wang et al., 2012). The control variables age, gender, education, and experience of using social media websites as confirmed by our study has no significant relation with purchase intentions. These variables have no power to affect the consumer purchase intentions in give research context.

\section{References}

Ahuja, M. K., \& Galvin, J. E. (2003). Socialization in virtual groups. Journal of Management, 29(2), 161-185. 


\section{INTERNATIONAL CONFERENCE ON BUSINESS, MANAGEMENT AND FINANCE}

UNITED KINGDOM | LONDON | March 7-9,2019

Algesheimer, R., Dholakia, U. M., \& Herrmann, A. (2005). The social influence of brand community: Evidence from European car clubs. Journal of Marketing, 69(3), 19-34.

Amaldoss, W., \& Jain, S. (2005). Pricing of conspicuous goods: A competitive analysis of social effects. Journal of Marketing Research, 42(1), 30-42.

Bagozzi, R. P., \& Dholakia, U. M. (2002). Intentional social action in virtual communities. Journal of Interactive Marketing, 16(2), 2-21.

Brown, J., Broderick, A. J., \& Lee, N. (2007). Word of mouth communication within online communities: Conceptualizing the online social network. Journal of Interactive Marketing, 21(3), 2-20.

Cheema, A., \& Kaikati, A. M. (2010). The effect of need for uniqueness on word of mouth. Journal of Marketing Research, 47(3), 553-563.

De Bruyn, A., \& Lilien, G. L. (2008). A multi-stage model of word-of-mouth influence through viral marketing. International Journal of Research in Marketing, 25(3), 151-163.

De Gregorio, F., \& Sung, Y. (2010). Understanding attitudes toward and behaviors in response to product placement. Journal of Advertising, 39(1), 83-96.

Dholakia, U. M., Bagozzi, R. P., \& Pearo, L. K. (2004). A social influence model of consumer participation in network-and small-group-based virtual communities. International Journal of Research in Marketing, 21(3), 241-263.

Gefen, D., \& Straub, D. W. (2000). The relative importance of perceived ease of use in IS adoption: A study of e-commerce adoption. Journal of the Association for information systems, $1(1), 8$.

Gershoff, A. D., \& Johar, G. V. (2006). Do you know me? Consumer calibration of friends' knowledge. Journal of consumer research, 32(4), 496-503.

Irmak, C., Vallen, B., \& Sen, S. (2010). You like what I like, but I don't like what you like: Uniqueness motivations in product preferences. Journal of consumer research, 37(3), 443-455. Islam, T., Attiq, S., Hameed, Z., Khokhar, M. N., \& Sheikh, Z. (2018). The Impact of Selfcongruity (Symbolic and Functional) on the Brand Hate: A Study Based on Self-Congruity Theory. British Food Journal(In Press).

islam, T., Sheikh, Z., Hameed, z., Khan, I. U., \& Azam, R. I. (2018). Social comparison, materialism, and compulsive buying based on stimulus-response-model: a comparative study among adolescents and young adults. Young Consumers(just-accepted), 00-00.

Islam, T., Wei, J., Sheikh, Z., Hameed, Z., \& Azam, R. I. (2017). Determinants of compulsive buying behavior among young adults: The mediating role of materialism. Journal of Adolescence, 61(Supplement doi:https://doi.org/10.1016/j.adolescence.2017.10.004

C),

117-130.

Khan, I. U., Hameed, Z., Yu, Y., Islam, T., Sheikh, Z., \& Khan, S. U. (2017). Predicting the acceptance of MOOCs in a developing country: Application of Task-Technology Fit Model, Social Motivation, and Self-determination Theory. Telematics and Informatics.

Köhler, C. F., Rohm, A. J., de Ruyter, K., \& Wetzels, M. (2011). Return on interactivity: The impact of online agents on newcomer adjustment. Journal of Marketing, 75(2), 93-108.

Krejcie, R. V., \& Morgan, D. W. (1970). Determining sample size for research activities. Educ psychol meas.

Kucuk, S. U, \& Krishnamurthy, S. (2007). An analysis of consumer 
power on the Internet. Technovation, 27(1), 47-56.

Levin, D. Z., \& Cross, R. (2004). The strength of weak ties you can trust: The mediating role of trust in effective knowledge transfer. Management science, 50(11), 1477-1490.

Lueg, J. E., Ponder, N., Beatty, S. E., \& Capella, M. L. (2006). Teenagers' use of alternative shopping channels: A consumer socialization perspective. Journal of retailing, 82(2), 137-153. Moschis, G. P., \& Churchill Jr, G. A. (1978). Consumer socialization: A theoretical and empirical analysis. Journal of Marketing Research, 599-609.

Mukhopadhyay, A., \& Yeung, C. W. (2010). Building character: Effects of lay theories of selfcontrol on the selection of products for children. Journal of Marketing Research, 47(2), 240250 .

Nambisan, S., \& Baron, R. A. (2007). Interactions in virtual customer environments: Implications for product support and customer relationship management. Journal of Interactive Marketing, 21(2), 42-62.

Okazaki, S. (2009).

The tactical use of mobile marketing: how adolescents' social networking can best shape brand extensions. Journal of Advertising Research, 49(1), 12-26.

Pookulangara, S., \& Koesler, K. (2011). Cultural influence on consumers' usage of social networks and its' impact on online purchase intentions. Journal of Retailing and Consumer Services, 18(4), 348-354.

Sheikh, Z., Islam, T., Rana, S., Hameed, Z., \& Saeed, U. (2017). Acceptance of social commerce framework in Saudi Arabia. Telematics and Informatics.

Singh, N., Chao, M. C., \& Kwon, I.-W. G. (2006). A MULTIVARIATE STATISTICAL APPROACH TO SOCIALIZATION AND CONSUMER ACTIVITIES OF YOUNG ADULTS: A CROSS-CULTURAL STUDY OF ETHNIC GROUPS IN AMERICA. Marketing Management Journal, 16(2).

Smith, D., Menon, S., \& Sivakumar, K. (2005). Online peer and editorial recommendations, trust, and choice in virtual markets. Journal of Interactive Marketing, 19(3), 15-37.

Statistics, I. Industry Statistics. Retrieved from http://www.bazaarvoice.com/

Taylor, D. G., Lewin, J. E., \& Strutton, D. (2011). Friends, fans, and followers: do ads work on social networks? Journal of Advertising Research, 51(1), 258-275.

Tian, K. T., Bearden, W. O., \& Hunter, G. L. (2001). Consumers' need for uniqueness: Scale development and validation. Journal of consumer research, 28(1), 50-66.

Wang, X., Yu, C., \& Wei, Y. (2012). Social Media Peer Communication and Impacts on Purchase Intentions: A Consumer Socialization Framework. Journal of Interactive Marketing, 26(4), 198-208. doi:http://dx.doi.org/10.1016/j.intmar.2011.11.004

Ward, S. (1974). Consumer socialization. Journal of consumer research, 1(2), 1-14.

Zaichkowsky, J. L. (1985). Measuring the involvement construct. Journal of consumer research, 12(3), 341-352.

Zhang, J., \& Daugherty, T. (2009). Third-person effect and social networking: Implications for online marketing and word-of-mouth communication. American Journal of Business, 24(2), 53-64. 